Gut, 1986, 27, 686-694

\title{
Inhibitory actions of loperamide on absorptive processes in rat small intestine
}

\author{
J HARDCASTLE, P T HARDCASTLE, AND J COOKSON \\ From the Department of Physiology, The University, Sheffield
}

SUMMARY Mucosal loperamide caused a dose dependent reduction in the absorption of actively transported hexoses and amino acids, together with the associated rise in short circuit current. $\mathrm{Na}^{+}$and fluid movement were also inhibited. Serosal application of the drug was without effect on these processes. The passive movement of fructose across the gut was not affected by loperamide which is therefore unlikely to act by reducing tissue permeability. In low $\mathrm{Na}^{+}$ conditions the inhibitory actions of loperamide on glycine absorption were reduced. Loperamide reduced basal $\mathrm{Na}^{+}$transport although it did not affect the stimulation of $\mathrm{Na}^{+}$absorption caused by mannose. Loperamide had no effect on the total ATPase activity nor on the $\mathrm{Na}^{+}, \mathrm{K}^{+}$-ATPase activity of mucosal homogenates. The effects of loperamide were not mimicked by morphine nor were they antagonised by naloxone and hence do not seem to involve an opiate receptor. It is concluded that loperamide exerts its inhibitory effects by an interaction with the $\mathrm{Na}^{+}$sites of the nutrient carriers.

Loperamide (Imodium, Janssen) is an opiate agonist which is used as an antidiarrhoeal agent. ${ }^{1}$ Its therapeutic efficacy appears to arise not only from an action on the motor functions of the intestine, which results in slowed intestinal transit and increased gut capacitance, ${ }^{2}$ but also from its ability to inhibit intestinal secretion. ${ }^{3-6}$ The antisecretory actions of loperamide are observed in response to serosal application of the drug. Loperamide is, however, administered orally and will therefore come into contact with the luminal surface of the intestinal epithelium, which is the site of absorptive processes in the intestine. The present investigation indicates that loperamide causes an inhibition of hexose and amino acid absorption and the associated movement of $\mathrm{Na}^{+}$and fluid in everted sacs of rat small intestine.

\section{Methods}

RATS

Experiments were carried out on male albino rats weighing between 230 and $250 \mathrm{~g}$. These were allowed free access to food (diet 86, Oxoid, London) and water. They were anaesthetised with sodium pentobarbitone $(60 \mathrm{mg} / \mathrm{kg}$ ip).

Address for correspondence: Dr J Hardcastle, Department of Physiology, University of Sheffield. Sheffield S10 2TN.

Received for publication 12 September 1985.
MEASUREMENT OF INTESTINAL TRANSPORT The everted intestinal sac, ${ }^{7}$ was used to determine the transport of fluid, nutrients, and $\mathrm{Na}^{+}$. Two $10 \mathrm{~cm}$ sacs, taken from the midintestine, were made. These were filled with $0.5 \mathrm{ml}$ fluid (serosal fluid) and incubated for 30 minutes at $37^{\circ} \mathrm{C}$ in $25 \mathrm{ml}$ fluid (mucosal fluid). The incubation fluid was Krebs bicarbonate saline ${ }^{8}$ equilibrated with $95 \%$ $\mathrm{O}_{2} / 5 \% \mathrm{CO}_{2}$ and containing additions as indicated. In experiments where the $\mathrm{Na}^{+}$concentration was reduced to $25 \mathrm{mM}$ this was achieved by replacing all the $\mathrm{NaCl}$ in the Krebs with isotonic Tris $\mathrm{Cl}$. Fluid transport was measured gravimetrically and the volume of fluid taken up by the sac, mucosal fluid transport, is expressed as $\mathrm{ml} / \mathrm{g}$ initial wet weight/ 30 minutes. The absorption of hexoses and amino acids was determined using ${ }^{14} \mathrm{C}$-labelled compounds $(1 \mu \mathrm{Ci} / 100 \mathrm{ml})$ which were added to the mucosal fluid containing unlabelled substrate at an initial concentration of $7.5 \mathrm{mM}$. At the end of the incubation period the serosal fluid was collected and the intestinal sac was deproteinised with $2 / 3 \mathrm{~N}_{2} \mathrm{SO}_{4}$ and $10 \%$ sodium tungstate, and homogenised. Samples were added to Bray's scintillation fluid ${ }^{9}$ and counted in a liquid scintillation counter (LKB, 1215 Rackbeta). Nutrient absorption was expressed in two ways: firstly as the amount taken up by the sac, expressed as $\mu \mathrm{mol} / \mathrm{g}$ initial wet weight $/ 30$ minutes, and secondly as the $T / M$ ratio. This is the ratio of 
nutrient concentration in the tissue water compared with that in the mucosal solution at the end of the incubation and is a measure of the concentrating ability of the intestine. Tissue concentration was calculated from the amount of nutrient in the tissue at the end of the incubation and the volume of tissue water $(80 \%$ initial wet weight plus the volume of fluid taken up by the sac during incubation). $\mathrm{Na}^{+}$ transport was measured by analysing the $\mathrm{Na}^{+}$ content of the final serosal fluid and gut homogenate using a Corning flame photometer (Model 430). Substrate and $\mathrm{Na}^{+}$uptake by the sacs was assessed by adding together the amounts in the gut homogenate and serosal fluid at the end of the incubation. Uptake is expressed as $\mu \mathrm{mol} / \mathrm{g}$ initial wet weight/ 30 minutes.

\section{MEASUREMENT OF INTESTINAL ELECTRICAL ACTIVITY}

Intestinal electrical activity was measured in paired sheets (tissue resistances did not vary by more than $20 \%$ ) of rat midintestine from which the muscle layers had been removed. These were clamped between two Perspex chambers and incubated at $37^{\circ} \mathrm{C}$ in $\mathrm{Krebs}$ bicarbonate saline ${ }^{8}$ gassed with $95 \% \mathrm{O}_{2} / 5 \% \mathrm{CO}_{2}$. The serosal solution contained $10 \mathrm{mM}$ glucose and the mucosal solution $10 \mathrm{mM}$ mannitol. The potential difference was measured by salt bridge electrodes connected via calomel half cells to a Vibron electrometer (Electronic Instruments Ltd, model 33B-2). Current was applied across the tissue using $\mathrm{Ag} / \mathrm{AgCl}$ electrodes which made contact with mucosal and serosal solutions via wide-bore salt bridges. When short circuiting the tissue, a correction was made for the resistance of the medium as described by Field, Fromm and McColl. ${ }^{10}$ After setting up, tissues were left for 10 minutes by which time a stable short circuit current had been achieved. Readings were then taken every minute for five minutes before the addition of either D-galactose or L-alanine. The rise in short circuit current induced by these nutrients was taken as the difference between the maximum value attained in their presence and the value immediately before their administration. When present, loperamide was added to the mucosal solution as soon as the preparation had been set up. Control tissues received an equivalent volume of the ethanol vehicle.

MEASUREMENT OF ATPASE ACTIVITY

The middle $20 \mathrm{~cm}$ of small intestine was removed from an anaesthetised rat and washed through with $0.9 \%$ saline. The intestinal segment was laid on a glass slab and opened along the mesenteric line. The mucosal surface was then gently scraped using a glass microscope slide to obtain a sample of mucosal cells. The ATPase activity of the unfractioned cell homogenates was measured using the method of Jorgensen ${ }^{11}$ with minor modifications. The mucosal scrape was added to incubation buffer to give a protein concentration of $1.5 \mathrm{mg} / \mathrm{ml}$, and homogenised by 10 strokes of a ground glass homogeniser. Protein content was determined by the method of Lowry et al. ${ }^{12}$ The incubation buffer had the following composition; $10 \mathrm{mM} \mathrm{MgCl}, 120 \mathrm{mM}$ $\mathrm{NaCl}, 20 \mathrm{mM} \mathrm{KCl}, 1 \mathrm{mM}$ EDTA, $60 \mathrm{mM}$ imidazole and $60 \mathrm{mM}$ Tris, $\mathrm{pH} \mathrm{7.5}$. Triton X-100 was present at a concentration of $0.0375 \%$ because preliminary experiments had shown this to be the optimum detergent concentration for 'activation' of ATPase in the preparation used. The mucosal homogenate was incubated for 30 minutes at room temperature so that the $\mathrm{Na}^{+}, \mathrm{K}^{+}$-ATPase could be 'activated'. It has been suggested by Jorgensen ${ }^{11}$ that the detergent activation of $\mathrm{Na}^{+}, \mathrm{K}^{+}$-ATPase is caused by exposure of latent enzyme sites in the preparation. After the 'activation' period, $25 \mu \mathrm{l}$ aliquots of the solution were transferred to test tubes containing $1 \mathrm{ml}$ of $3 \mathrm{mM}$ ATP in incubation buffer for enzyme assay. The tubes were incubated at $37^{\circ} \mathrm{C}$ for 30 minutes and at the end of this time the reaction was terminated by the addition of $100 \mu \mathrm{l} 50 \%$ trichloroacetic acid. Liberated inorganic phosphate was then assayed by Allen's ${ }^{13}$ modification of the Fiske and Subbarow ${ }^{14}$ method and enzyme activity was expressed as $\mu \mathrm{mol} \mathrm{Pi} / \mathrm{mg}$ protein $/ \mathrm{h}$. For each experimental condition the incubation was carried out in the absence and presence of $1 \mathrm{mM}$ ouabain. $\mathrm{Na}^{+}$, $\mathrm{K}^{+}$-ATPase activity was taken as the difference between values obtained with and without ouabain. Loperamide was added to the incubation buffer to give the assay concentrations indicated. Preliminary experiments showed that the ethanol vehicle had no significant effect on either total ATPase activity or $\mathrm{Na}^{+}, \mathrm{K}^{+}$-ATPase activity ( $\mathrm{p}>0.05$ in all cases).

\section{EXPRESSION OF RESULTS}

Results are expressed as mean values \pm 1 SEM of the number of observations indicated. Significance was assessed using Student's $t$ test, paired or unpaired as appropriate.

\section{CHEMICALS}

Glycine, L-alanine, D-galactose, D-mannose and Dfructose were obtained from BDH Chemicals Ltd, Poole, England. Ethylene diamine tetra-acetic acid, Tris base, imidazole, and naloxone were obtained from the Sigma Chemical Co, St. Louis, MO 63178, U.S.A. Loperamide was generously supplied by Janssen Pharmaceutical Ltd., Beerse, Belgium. D$\left[1-{ }^{14} \mathrm{C}\right]$ galactose, $\left[\mathrm{U}-{ }^{14} \mathrm{C}\right]$ glycine and $\mathrm{D}-\left[\mathrm{U}-{ }^{14} \mathrm{C}\right]$ 
fructose were supplied by Amersham International PLC, Amersham, Bucks, England.

\section{Results}

EFFECTS OF LOPERAMIDE AND MORPHINE ON GLYCINE AND FLUID TRANSPORT

The presence of loperamide in the mucosal solution reduced the total amount of glycine taken up and the $\mathrm{T} / \mathrm{M}$ ratio achieved by everted sacs of intestine in a dose-dependent manner (Table 1, Fig. 1). This effect was significant at $1.9 \times 10^{-5} \mathrm{M}$. The effect of loperamide on fluid absorption in these experiments was less marked, no significant effect being observed until a concentration of $9.5 \times 10^{-5} \mathrm{M}$ was reached. Loperamide caused a $50 \%$ inhibition of glycine transport at a concentration of $1.2 \times 10^{-4} \mathrm{M}$ and a $50 \%$ inhibition of fluid transport at $3 \cdot 1 \times 10^{-4} \mathrm{M}$. In all cases the ethanol vehicle used had no significant effect on any of the indices measured ( $p>0 \cdot 05$ in all cases). Serosal application of hyperamide $(9 \cdot 5 \times$ $\left.10^{-5} \mathrm{M}\right)$ was without significant effect $(p>0.05)$ on glycine and fluid transport. In contrast with the actions of loperamide, mucosal morphine had no effect on fluid and glycine absorption (Table 1).

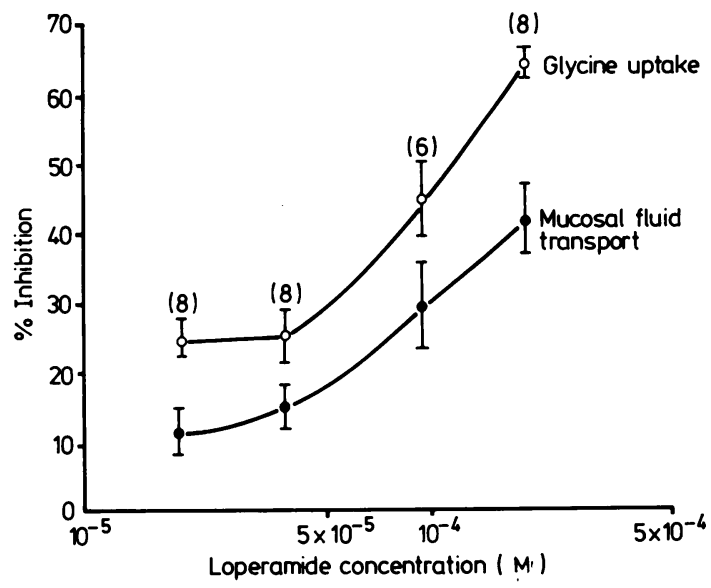

Fig. 1 Inhibition of fluid and glycine absorption by everted sacs of rat midintestine in the presence of varying concentrations of mucosal loperamide. Absorption in the presence of loperamide was compared with values obtained in control experiments where the mucosal fluid contained an equivalent volume of the ethanol vehicle, and $a \%$ inhibition calculated. Absolute values are given in Table 1. Each value represents the mean $\pm 1 S E$ of the mean of the number of observations indicated.

Table 1 Effect of varying concentrations of loperamide and morphine in the mucosal fluid on fluid and glycine absorption by everted sacs of rat mid-intestine. Glycine transport is expressed as the amount taken up during the incubation ( $\mathrm{glycine}$ uptake) and as the tissue: mucosal fluid concentration ratio (T/M) achieved by the end of the incubation. Experiments were also conducted in which the mucosal surface of the sac was exposed to the appropriate concentration of the ethanol vehicle. This did not alter significantly ( $p>0.05$ in all cases) any of the indices measured. Results are expressed as mean values \pm 1 SE of the mean of the number of observations in parentheses. Significance was assessed using an unpaired test.

\begin{tabular}{|c|c|c|c|}
\hline Additions to mucosal fluid & $\begin{array}{l}\text { Mucosal fluid transport } \\
(\mathrm{ml} / \mathrm{g} \text { iww/30 } \mathrm{min})\end{array}$ & $\begin{array}{l}\text { Glycine uptake } \\
(\mu \mathrm{mol} / \mathrm{g} \text { iww/30 min) }\end{array}$ & $T / M$ \\
\hline No additions (16) & $0.53 \pm 0.03$ & $27 \cdot 2 \pm 1 \cdot 8$ & $2 \cdot 5 \pm 0 \cdot 2$ \\
\hline $0.2 \mathrm{ml} \%$ ethanol (8) & $0.52 \pm 0.05$ & $32 \cdot 8 \pm 3 \cdot 2$ & $3 \cdot 0 \pm 0 \cdot 3$ \\
\hline \multirow[t]{2}{*}{$1.9 \times 10^{-5} \mathrm{M}$ loperamide (8) } & $0 \cdot 46 \pm 0 \cdot(02$ & $24 \cdot 7 \pm 0 \cdot 9$ & $2 \cdot 2 \pm 0 \cdot 1$ \\
\hline & NS & $\mathrm{p}<0.05$ & $\mathrm{p}<0 \cdot 05$ \\
\hline $0.4 \mathrm{ml} \%$ ethanol (7) & $(0 \cdot 61 \pm 0 \cdot(04$ & $27 \cdot 9 \pm 1 \cdot 7$ & $2 \cdot 5 \pm 0 \cdot 1$ \\
\hline \multirow[t]{2}{*}{$3.8 \times 10^{-5} \mathrm{M}$ loperamide $(8)$} & $(0 \cdot 52 \pm 0 \cdot() 2$ & $20 \cdot 9 \pm 1 \cdot 0$ & $1 \cdot 8 \pm 0 \cdot 1$ \\
\hline & NS & $\mathrm{p}<0 \cdot 01$ & $\mathrm{p}<0 \cdot 001$ \\
\hline $0.5 \mathrm{ml} \%$ ethanol (10) & $0 \cdot 60 \pm 0 \cdot(05$ & $25 \cdot 9 \pm 1 \cdot 7$ & $2 \cdot 2 \pm 0 \cdot 1$ \\
\hline \multirow[t]{2}{*}{$9.5 \times 10^{-5} \mathrm{M}$ loperamide (6) } & $(0 \cdot 43 \pm(0 \cdot 04$ & $14 \cdot 3 \pm 1 \cdot 4$ & $1 \cdot 3 \pm 0 \cdot 1$ \\
\hline & $\mathrm{p}<0 \cdot(05$ & $\mathrm{p}<0.001$ & $\mathrm{p}<0.001$ \\
\hline $0.8 \mathrm{ml} \%$ ethanol $(20)$ & $0.48 \pm 0.03$ & $26 \cdot 0 \pm 1 \cdot 4$ & $2 \cdot 4 \pm 0 \cdot 1$ \\
\hline \multirow[t]{2}{*}{$1.9 \times 10^{-4} \mathrm{M}$ loperamide $(8)$} & $0 \cdot 28 \pm 0 \cdot(02$ & $9 \cdot 3 \pm 0 \cdot 6$ & $1 \cdot() \pm 0 \cdot 1$ \\
\hline & $\mathrm{p}<0 \cdot(0) 1$ & $\mathrm{p}<0 \cdot(0) 1$ & $\mathrm{p}<0.001$ \\
\hline No additions (8) & $0.54 \pm 0.05$ & $26 \cdot 5 \pm 2 \cdot 5$ & $2 \cdot 4 \pm 0 \cdot 2$ \\
\hline \multirow[t]{2}{*}{$1 \cdot 3 \times 10^{-4} \mathrm{M}$ morphine $(8)$} & $(0 \cdot 52 \pm 0 \cdot 03$ & $25 \cdot() \pm 1 \cdot 8$ & $2 \cdot 3 \pm 0 \cdot 2$ \\
\hline & NS & NS & NS \\
\hline No additions (8) & $(0 \cdot 60 \pm 0 \cdot(0) 2$ & $29 \cdot 6 \pm 0 \cdot 5$ & $2 \cdot 9 \pm 0 \cdot 1$ \\
\hline \multirow[t]{2}{*}{$10^{-3} \mathrm{M}$ morphine $(7)$} & $0.55 \pm 0 \cdot(04$ & $27 \cdot 0 \pm 2 \cdot()$ & $2 \cdot 7 \pm 0 \cdot 2$ \\
\hline & NS & NS & NS \\
\hline
\end{tabular}


EFFECTS OF LOPERAMIDE ON GALACTOSE AND FLUID TRANSPORT

Loperamide also reduced the absorption of galactose, a hexose that is not metabolised significantly by rat small intestine. At a concentration of $9 \cdot 5 \times$ $10^{-5} \mathrm{M}$ in the mucosal fluid, loperamide reduced galactose uptake from $44 \cdot 4 \pm 2 \cdot 3[n=7]$ to $26 \cdot 1 \pm$ $2.4[\mathrm{n}=7] \mu \mathrm{mol} / \mathrm{g}$ iww/30 $\mathrm{min}(\mathrm{p}<0.001)$ and the $\mathrm{T} / \mathrm{M}$ ratio from $4 \cdot 4 \pm 0 \cdot 3[\mathrm{n}=7]$ to $2 \cdot 5 \pm 0 \cdot 2[\mathrm{n}=7]$ $(\mathrm{p}<0.001)$. There was also a decrease in fluid absorption from $0.50 \pm 0.03 \quad[n=7]$ to $0.32 \pm$ $0.02[\mathrm{n}=7] \mathrm{ml} / \mathrm{g}$ iww/30 $\mathrm{min}(\mathrm{p}<0.001)$.

\section{EFFECT OF LOPERAMIDE ON FRUCTOSE AND} FLUID MOVEMENT

Under the experimental conditions used in this study there was no evidence of active fructose absorption since the $T / M$ ratio was less than 1 $(0.64 \pm 0.02[n=8])$. Under control conditions the intestinal preparation took up $7 \cdot 4 \pm 0 \cdot 6[n=8]$ $\mu \mathrm{mol}$ fructose/g iww/30 min and this was not altered significantly $(p>0.05)$ by loperamide $(9.5 \times$ $10^{-5} \mathrm{M}$ in the mucosal fluid). Similarly loperamide failed to affect the $T / M$ ratio $(p>0.05)$ in these experiments.

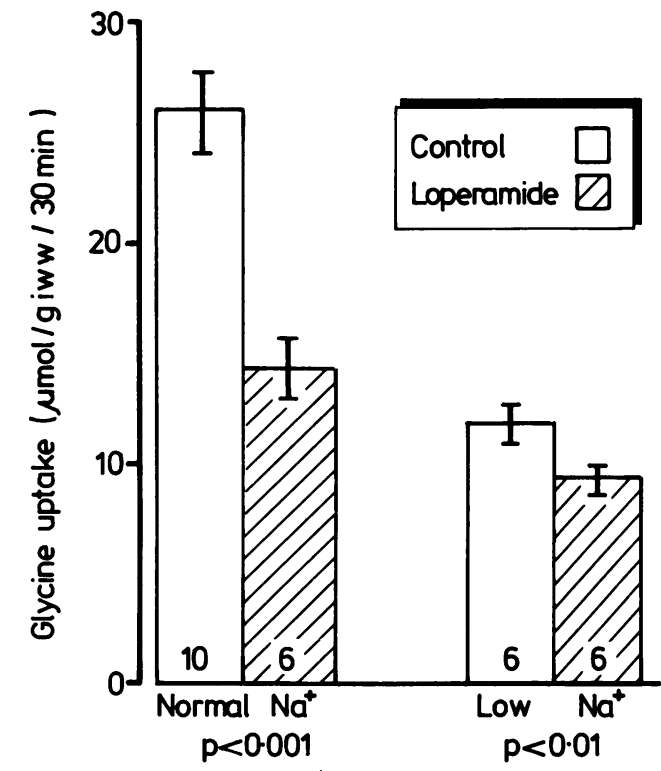

Fig. 2 Effect of mucosal loperamide $\left(9.5 \times 10^{-5} \mathrm{M}\right.$ on glycine uptake in normal Krebs bicarbonate saline $\left(\mathrm{Na}^{+}=143 \mathrm{mM}\right)$ and when the mucosal $\mathrm{Na}^{+}$ concentration was reduced to $25 \mathrm{mM}$ (low $\mathrm{Na}^{+}$) by partial replacement of $\mathrm{Na}^{+}$with Tris ${ }^{+}$. Control sacs were exposed to an equivalent volume of the ethanol vehicle. Each bar represents the mean $\pm 1 S E$ of the mean of the number of observations indicated. Significance of loperamide action was assessed using an unpaired t test.

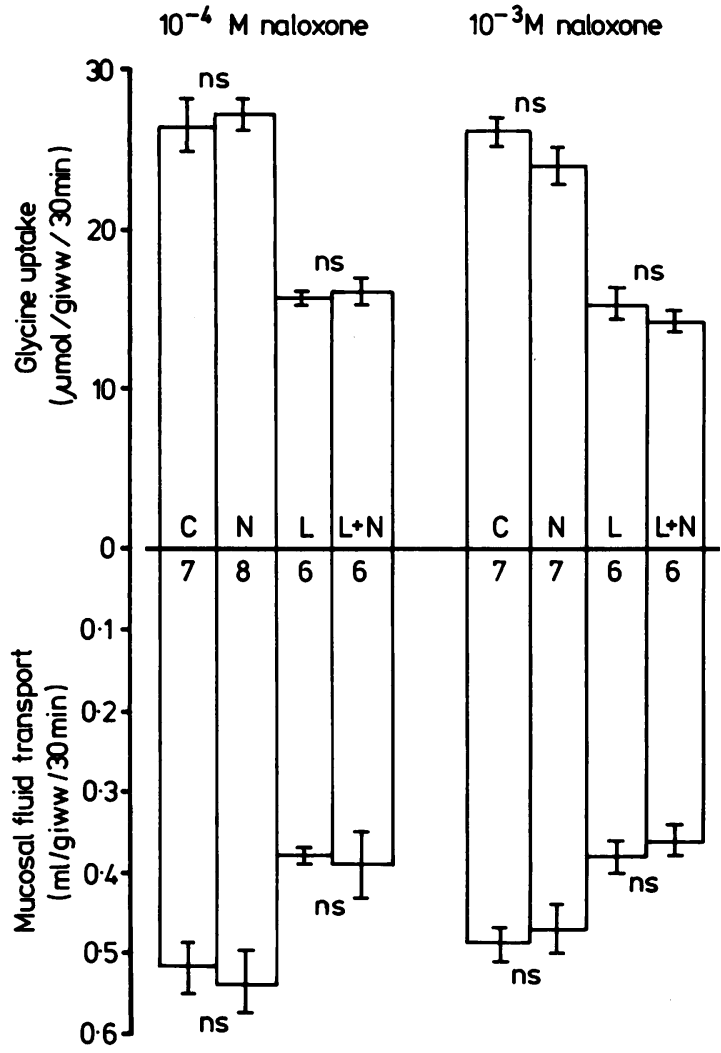

Fig. 3 Effect of naloxone $\left(10^{-4} \mathrm{M}\right.$ or $\left.10^{-3} \mathrm{M}\right)$ in the mucosal fluid on glycine and fluid transport in the absence and presence of loperamide $\left(9.5 \times 10^{-5} \mathrm{M}\right.$ in mucosal fluid). Experiments were carried out under control conditions $(C)$, with naloxone $(N)$, with loperamide $(L)$ and with both loperamide and naloxone $(L+N)$. Results are expressed as mean values $\pm 1 S E$ of the mean of the number of observations indicated. Significance of naloxone action was assessed using an unpaired t test.

EFFECT OF LOPERAMIDE ON GLYCINE TRANSPORT IN LOW $\mathrm{Na}^{+}$CONDITIONS

Reducing the mucosal $\mathrm{Na}^{+}$concentration to $25 \mathrm{mM}$ caused a significant $(\mathrm{p}<0 \cdot 001)$ reduction in the uptake of glycine (Fig. 2). Under these conditions loperamide was much less effective in reducing glycine absorption, causing only a $20 \cdot 6 \pm 5 \cdot 1 \%[n=6]$ inhibition, which compares with the $44 \cdot 6 \pm 5.4 \%$ $[\mathrm{n}=6](\mathrm{p}<0.01)$ observed when the $\mathrm{Na}^{+}$concentration was normal (Fig. 2). In addition, the $\mathrm{Na}^{+}$dependence of glycine absorption was reduced significantly $(p<0.01)$ in the presence of loperamide, since lowering the $\mathrm{Na}^{+}$concentration caused a $35 \cdot 7 \pm 4 \cdot 2 \%[n=6]$ inhibition of glycine uptake in the presence of the drug and a $54 \cdot 8 \pm 3 \cdot 1 \%[n=6]$ inhibition in its absence. These observations are 
Table 2 Effect of loperamide on fluid and $\mathrm{Na}^{+}$absorption by everted sacs of rat midintestine. Loperamide was present in the mucosal fluid at a concentration of $9 \cdot 5 \times 10^{-5} \mathrm{M}$ while in control experiments an equivalent volume of the ethanol vehicle was added. When present, glycine was added to the mucosal fluid to give a concentration of 7.5 mM while mannose was added to the serosal fluid to give a concentration of $222 \mathrm{mM}$. Each value represents the mean $\pm 1 S E$ of the mean of the number of observations in parentheses. The significance of loperamide action was assessed using an unpaired test.

\begin{tabular}{|c|c|c|c|}
\hline & $\begin{array}{l}\text { Mucosal fluid transport } \\
(\mathrm{ml} / \mathrm{g} \text { iww } / 30 \mathrm{~min})\end{array}$ & $\begin{array}{l}\mathrm{Na}^{+} \text {uptake } \\
(\mu \mathrm{mol} / \mathrm{g} \text { iww/30 } \mathrm{min})\end{array}$ & $\begin{array}{l}\text { Glycine-dependent } \\
\mathrm{Na}^{+} \text {transfer } \\
(\mu \mathrm{mol} / \mathrm{g} \text { iww/30 min })\end{array}$ \\
\hline Control (7) & $0 \cdot 40 \pm 0 \cdot 01$ & $68 \cdot 7 \pm 1 \cdot 7$ & \\
\hline Loperamide (7) & $\begin{array}{l}0.33 \pm 0.02 \\
0<0.01\end{array}$ & $\begin{array}{l}56 \cdot 0 \pm 4.2 \\
\mathfrak{p}<0.05\end{array}$ & \\
\hline Glycine (7) & $0.49 \pm 0.03$ & $90 \cdot 5 \pm 4 \cdot 5$ & $21 \cdot 8 \pm 4 \cdot 5$ \\
\hline Glycine + loperamide (7) & $\begin{array}{l}0 \cdot 37 \pm 0.02 \\
\mathrm{p}<0.01\end{array}$ & $\begin{array}{l}65 \cdot 9 \pm 2 \cdot 0 \\
p<0.001\end{array}$ & $\begin{array}{l}9.9 \pm 2 \cdot 0 \\
p<0.05\end{array}$ \\
\hline Mannose (7) & $0.94 \pm 0.05$ & $132 \cdot 0 \pm 7 \cdot 3$ & \\
\hline Mannose + loperamide (8) & $\begin{array}{l}0.96 \pm 0 \cdot 05 \\
\text { NS }\end{array}$ & $\begin{array}{l}133 \cdot 3 \pm 6 \cdot 4 \\
\text { NS }\end{array}$ & \\
\hline Glycine+mannose (6) & $1.34 \pm 0.07$ & $176 \cdot 6 \pm 10 \cdot 3$ & $44 \cdot 6 \pm 10 \cdot 3$ \\
\hline Glycine + mannose +loperamide $(8)$ & $\begin{array}{l}1 \cdot 13 \pm 0 \cdot 05 \\
p<0 \cdot 05\end{array}$ & $\begin{array}{l}147 \cdot 9 \pm 8 \cdot 5 \\
p<0.05\end{array}$ & $\begin{array}{l}14 \cdot 6 \pm 8 \cdot 5 \\
p<0 \cdot 05\end{array}$ \\
\hline
\end{tabular}

consistent with an action of loperamide at the $\mathrm{Na}^{+}$ site of the nutrient carrier.

\section{EFFECTS OF NALOXONE ON GLYCINE AND FLUID ABSORPTION \\ Naloxone alone had no effect on fluid or glycine transport, nor did it antagonise the inhibitory actions of loperamide (Fig. 3).}

\section{EFFECTS OF LOPERAMIDE ON $\mathrm{Na}^{+}$AND FLUID TRANSPORT}

In the absence of glycine, loperamide caused a small inhibition of fluid transport $(17 \cdot 5 \pm 4 \cdot 7 \%[n=6])$ and $\mathrm{Na}^{+}$uptake $(18 \cdot 5 \pm 6 \cdot 1 \%[\mathrm{n}=6])$ by the intestinal sacs (Table 2). These effects of loperamide on basal fluid and $\mathrm{Na}^{+}$transport were less marked $(\mathrm{p}<0.01$ in both cases) than the $44 \cdot 6 \pm 5 \cdot 4 \%[n=6]$ inhibition of glycine absorption observed at the same concentration of the drug (Table 1). Glycine stimulated both fluid $(\mathrm{p}<0.05)$ and $\mathrm{Na}^{+}$transport $(\mathrm{p}<0.01)$ significantly, but in the presence of loperamide $\left(9.5 \times 10^{-5} \mathrm{M}\right)$, these effects were reduced. Thus as well as inhibiting glycine transport, loperamide also reduces the $\mathrm{Na}^{+}$and fluid movement associated with nutrient absorption.

The increased $\mathrm{Na}^{+}$transport associated with nutrient absorption takes place via an electrogenic pathway. ${ }^{15} 16$ In sheets of rat midintestine, the increased short circuit current generated by this $\mathrm{Na}^{+}$ movement in the presence of alanine and galactose was reduced significantly when loperamide $(9 \cdot 5 \times$ $10^{-5} \mathrm{M}$ ) was added to the mucosal solution (Fig. 4). In these experiments alanine was used instead of glycine. Alanine is absorbed by the same transport systems as glycine but it produces a larger increase in short-circuit current. The reason for this is not known.

Loperamide did not alter significantly the marked stimulation of fluid and $\mathrm{Na}^{+}$absorption induced by

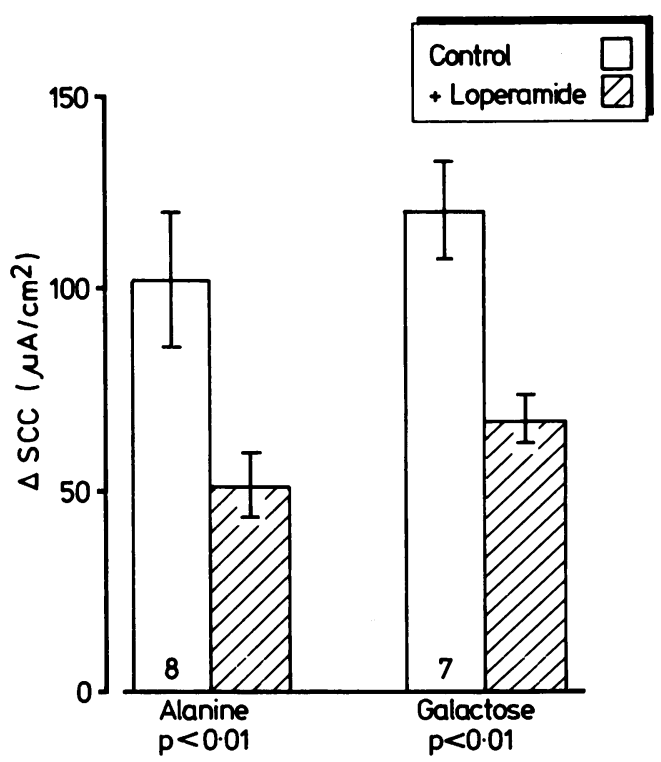

Fig. 4 Effect of loperamide $\left(9.5 \times 10^{-5} \mathrm{M}\right.$ in the mucosal fluid) on the rise in short circuit current $(\triangle S C C)$ observed with L-alanine and D-galactose (7.5 $\mathrm{mM}$ in the mucosal fluid) in sheets of rat midintestine. Experiments were carried out with paired tissues and the control preparation received an equivalent volume of the vehicle (ethanol). Each bar represents the mean $\pm 1 S E$ of the mean of the number of observations indicated. Significance was assessed using a paired t test. 
the metabolisable hexose, mannose (Table 2). This sugar is known to increase the absorption of $\mathrm{Na}^{+}$by a neutral pathway ${ }^{17}$ and it appears that this mechanism is not susceptible to inhibition by loperamide. In the presence of mannose, glycine stimulated significantly the absorption of both fluid $(p<0.001)$ and $\mathrm{Na}^{+}(\mathrm{p}<0 \cdot 01)$ and these effects were reduced by loperamide (Table 2 ).

\section{EFFECT OF LOPERAMIDE ON THE KINETICS OF NUTRIENT ABSORPTION}

The electrical technique was used to assess the effects of loperamide on the kinetics of nutrient absorption, as the rise in short circuit current induced by nutrients is directly related to their rates of transport. ${ }^{15} 16$ The rise in short circuit current caused by serial additions of alanine or galactose to the mucosal fluid exhibited saturation kinetics (Fig. 5 ). The $\mathrm{J}_{\max }$ (maximum rise in short circuit current) and apparent $\mathrm{K}_{\mathrm{t}}$ (apparent Michaelis constant) were calculated in two ways: firstly from a LineweaverBurk plot of the data and secondly from a direct linear plot. ${ }^{18}$ These two methods produced values that did not differ significantly from one another ( $p>0.05$ in all cases). Loperamide reduced the rise in short circuit current induced by both alanine and galactose (Fig. 5) and this was reflected in lower $\mathrm{J}_{\max }$ values in the presence of the drug (Table 3 ). Loperamide also reduced the apparent $K_{t}$ for both nutrients (Table 3). It has been pointed out, however, that changes in $\mathrm{J}_{\max }$ can create artefactual alterations in the apparent $\mathrm{K}_{\mathrm{t}}{ }^{18}$, and so the decreased values for apparent $K_{t}$ observed in these experiments are likely to be a consequence of the reduced $J_{\max }$ rather than a change in the affinity of the carriers for nutrients.

\section{EFFECT OF LOPERAMIDE ON $\mathrm{Na}^{+}, \mathrm{K}^{+}$- ATPASE ACTIVITY}

The total ATPase activity was $42 \cdot 2 \pm 2 \cdot 3[\mathrm{n}=9] \mu \mathrm{mol}$ $\mathrm{Pi} / \mathrm{mg}$ protein/h and $\mathrm{Na}^{+}, \mathrm{K}^{+}$-ATPase activity was $14.9 \pm 1.0[\mathrm{n}=9] \mu \mathrm{mol} \mathrm{Pi} / \mathrm{mg}$ protein/h. Neither of these values was affected significantly by loperamide ( $\mathrm{p}>0 \cdot 05, \mathrm{n}=4$ in both cases).

\section{Discussion}

The small intestine possesses both absorptive and secretory mechanisms. The net movement of fluid depends on a balance between these absorptive and secretory processes. Normally absorption exceeds
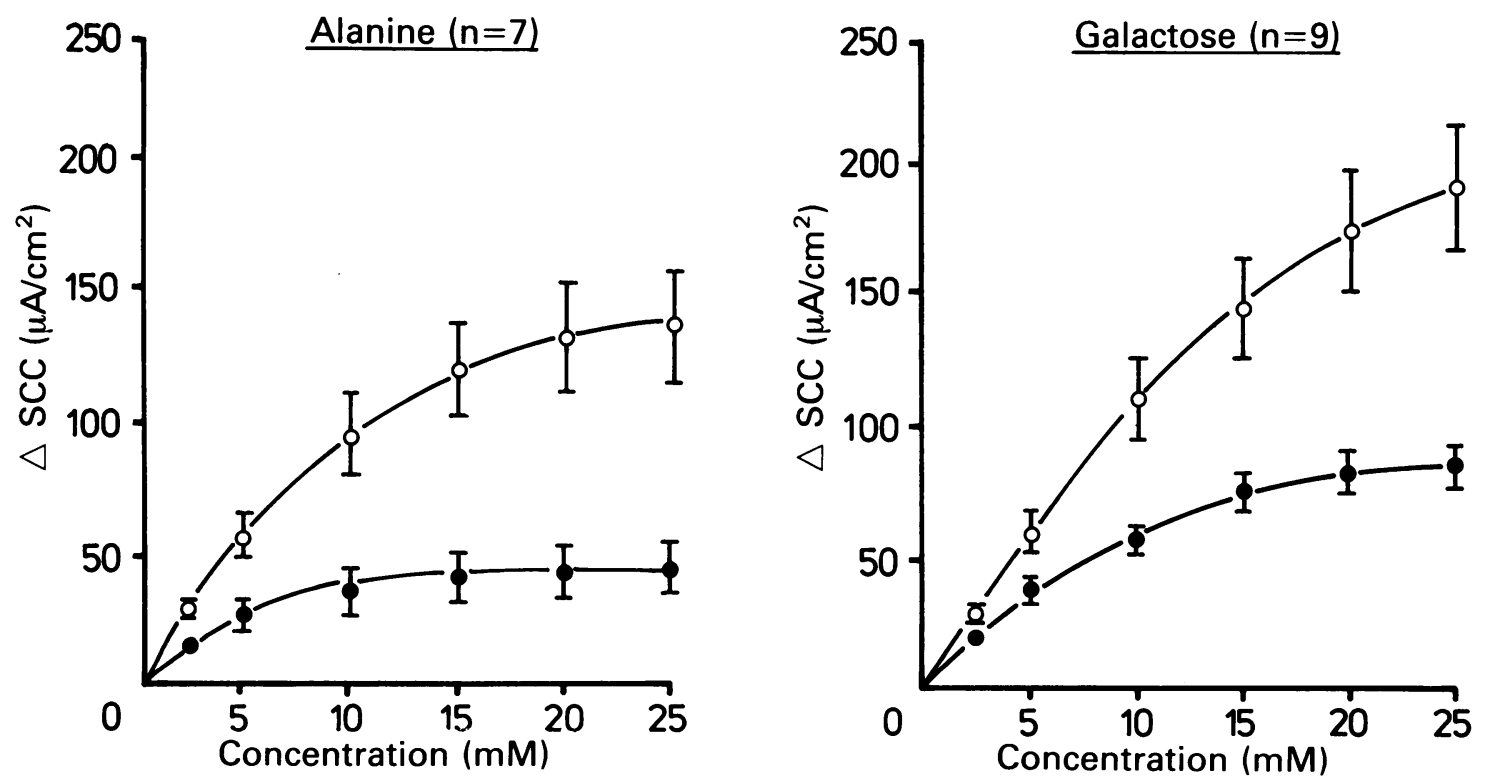

Fig. 5 Effect of mucosal loperamide $\left(1.9 \times 10^{-4} \mathrm{M}\right)$ on the kinetics of alanine and galactose absorption. Experiments were carried out on paired sheets of rat mid-intestine and nutrient absorption was monitored as a rise in short-circuit current $(\triangle S C C)$. Loperamide was added to the mucosal fluid of test sheets (O) while an equivalent volume of ethanol (I ml\%) was added to the mucosal fluid of control sheets $(O)$. Each value represents the mean \pm ISE of the mean of the number of observations indicated. 
Table 3 Effect of mucosal loperamide $\left(1.9 \times 10^{-4} \mathrm{M}\right.$ ) on the $J_{\max }\left(\right.$ maximum rise in short-circuit current $\left.-\mu A / \mathrm{cm}^{2}\right)$ and apparent $K_{t}$ (apparent Michaelis constant - $\left.m M\right)$ for alanine and galactose. Experiments were carried out in paired stripped sheets of rat mid-intestine and the mucosal surface of the control tissue was exposed to an equivalent volume of the ethanol vehicle. Kinetic parameters were calculated using a Lineweaver-Burk plot (first values) and a direct linear plot (values in parentheses). Each value represents the mean \pm 1 SE of the mean of the number of tissue pairs indicated. The significance of loperamide action was assessed using a paired t test.

\begin{tabular}{|c|c|c|c|c|}
\hline & & Control & + Loperamide & $P$ \\
\hline \multirow[t]{2}{*}{ Alanine (7) } & $J_{\max }$ & $\begin{array}{c}256 \pm 45 \\
(223 \pm 35)\end{array}$ & $\begin{array}{c}61 \pm 14 \\
(60 \pm 14)\end{array}$ & $\begin{array}{l}<0 \cdot(0) 1 \\
(<0 \cdot(0) 1)\end{array}$ \\
\hline & Apparent $K_{t}$ & $\begin{array}{c}18 \cdot 2 \pm 3 \cdot 0 \\
(16 \cdot 9 \pm 2 \cdot 1)\end{array}$ & $\begin{array}{c}7 \cdot 0 \pm 0 \cdot 5 \\
(7 \cdot() \pm 0 \cdot 8)\end{array}$ & $\begin{array}{l}<0 \cdot 05 \\
(<0 \cdot(01)\end{array}$ \\
\hline \multirow[t]{2}{*}{ Galactose (9) } & $\mathrm{J}_{\max }$ & $\begin{array}{c}408 \pm 61 \\
(413 \pm 64)\end{array}$ & $\begin{array}{c}149 \pm 23 \\
(146 \pm 24)\end{array}$ & $\begin{array}{l}<0 \cdot(01 \\
(<0 \cdot(01)\end{array}$ \\
\hline & Apparent $\mathrm{K}_{\mathrm{t}}$ & $\begin{array}{c}26 \cdot 4 \pm 2 \cdot 8 \\
(26 \cdot 9 \pm 3 \cdot 5)\end{array}$ & $\begin{array}{c}14 \cdot 6 \pm 2 \cdot 6 \\
(15 \cdot 2 \pm 3 \cdot())\end{array}$ & $\begin{array}{c}<0 \cdot(01 \\
(<0 \cdot(01)\end{array}$ \\
\hline
\end{tabular}

secretion and there is a net movement of fluid into the blood. If, however, this balance is reversed, diarrhoea can result. Such an imbalance can be either because of a stimulation of secretion or an inhibition of absorption. The antidiarrhoeal efficacy of loperamide is due, at least in part, its ability to inhibit secretory processes in the small intestine. In addition, it now appears that loperamide can also influence absorptive mechanisms in the gut. Thus the overall effect of loperamide on net fluid movement will be determined by its relative antisecretory and antiabsorptive actions as well as on the initial balance between absorption and secretion.

Exposure of the luminal surface of the intestine to loperamide reduced the absorption of glycine and the $\mathrm{Na}^{+}$and fluid transport associated with it, in everted sacs of rat mid-intestine (Tables 1 and 2). Galactose transport was similarly affected by mucosal administration of the drug. In contrast, serosal application of loperamide was without effect on these processes. The inhibitory actions of mucosal loperamide seem to be directed primarily towards the mechanisms for active nutrient absorption, because basal fluid and $\mathrm{Na}^{+}$transport were much less affected by the drug. In addition, the movement of fructose, a hexose which was not actively absorbed in these experiments, was unaltered by the drug. How the loperamide concentrations used in the present study relate to the luminal concentration in the intestine after oral ingestion of a typical dose ( $4 \mathrm{mg}$ ) is not known, as no values have been reported. Loperamide has, however, been perfused intraluminally in man ${ }^{19}$ at concentrations that are comparable with those used in this investigation.

It has been shown in the colon that loperamide reduces paracellular permeability. ${ }^{20}$ It is unlikely, however, that the inhibition of active nutrient absorption observed in this study can be attributed to this cause, as the passive movement of fructose was unaffected by the drug.

The active absorption of nutrients by the small intestine utilises the energy from the electrochemical gradient for $\mathrm{Na}^{+}$across the luminal membrane. This is harnessed by means of carriers which have two sites - one for the nutrient and one for $\mathrm{Na}^{+}$. When both sites are occupied the carrier crosses the membrane and the nutrient and $\mathrm{Na}^{+}$enter the enterocyte. In order to maintain the $\mathrm{Na}^{+}$gradient, this $\mathrm{Na}^{+}$is removed by an electrogenic $\mathrm{Na}^{+}$pump situated on the basolateral membrane. ${ }^{21}$ The increased activity of this pump is responsible for the rise in short circuit current associated with nutrient absorption (Fig. 4). This change was reduced in the presence of luminal loperamide (Fig. 4), reflecting the observed inhibition of $\mathrm{Na}^{+}$transport associated with nutrient absorption (Table 2). In rabbit ileum mucosal loperamide was seen to have no effect on the short circuit current even though glucose was present in the bathing solution. ${ }^{22}$ Close examination of the data, however, does suggest a small inhibition of electrical activity after 40 minutes exposure to the drug which was present at a concentration $\left(10^{-6} \mathrm{M}\right)$ that was lower than that used in the present study.

Because nutrient absorption depends on the maintenance of the $\mathrm{Na}^{+}$gradient across the luminal membrane, loperamide action could be caused by an inhibition of the $\mathrm{Na}^{+}$pump. This seems unlikely, however, for two reasons. Firstly, loperamide failed to inhibit the absorption of $\mathrm{Na}^{+}$stimulated by mannose (Table 2). In this process $\mathrm{Na}^{+}$is absorbed in association with $\mathrm{Cl}^{-}$by a neutral pathway ${ }^{23}$ that also utilises energy from the $\mathrm{Na}^{+}$gradient. ${ }^{24}$ As this pathway was unaffected by loperamide the $\mathrm{Na}^{+}$ gradient must be normal. These experiments also 
indicate that the metabolic energy supply of the cell was unaffected by the drug. Secondly, loperamide did not reduce the activity of $\mathrm{Na}^{+}, \mathrm{K}^{+}$-ATPase, the enzyme that is associated with the $\mathrm{Na}^{+}$pump. Thus loperamide does not appear to influence $\mathrm{Na}^{+}$pump activity. It is therefore more likely that loperamide acts at the nutrient carriers situated on the luminal membrane. Sugars and amino acids use different carriers but these all have a common requirement for $\mathrm{Na}^{+}$. As loperamide inhibits the absorption of both types of nutrient it may therefore exert its effect at the $\mathrm{Na}^{+}$sites of the carriers as has been postulated for harmaline. ${ }^{25}$ The fact that loperamide was much less effective when the $\mathrm{Na}^{+}$gradient was reduced (Fig. 2) is consistent with this view. An action of loperamide at the $\mathrm{Na}^{+}$site could prevent the nutrient carrier from utilising the energy of the $\mathrm{Na}^{+}$gradient and this would explain the decreased $\mathrm{J}_{\max }$ observed in the presence of the drug (Table 3 ).

Some studies in man using segmental jejunal perfusion, have indicated that the antidiarrhoeal effects of loperamide may result from an inhibition of secretion. ${ }^{26}$ Schiller et al, ${ }^{2}$ however, have reported that the action of loperamide is solely because of a change in motor function and not to an alteration in the rate of transport. These experiments were performed by infusing a balanced electrolyte solution into the stomach and hence the lack of effect of loperamide on absorption is consistent with the data reported here, where loperamide acted primarily on the transport functions associated with nutrient absorption.

The inhibitory effect of loperamide was not a general action shown by other opiate agonists, because morphine, an agonist for the $\mu$-receptor, did not produce any inhibition of nutrient absorption (Table 1), even though it has similar antisecretory actions to loperamide. ${ }^{27}$ The opiate antagonist naloxone has been reported to block the antisecretory actions of loperamide, ${ }^{6}$ but in the present investigation it did not antagonise the effects of loperamide on fluid and nutrient absorption at either of the doses used (Fig. 3). There appear to be multiple opiate receptors in existence in the small intestine and most agonists and antagonists are capable of interacting with more than one type of receptor. ${ }^{28}$ Although this complicates the determination of the receptor involved in any particular physiological response, the $\mu$-receptor has been reported to be primarily involved with motility while the $\delta$-receptor is principally involved with transport. ${ }^{29}$ Naloxone interacts with both these receptor types although it has a greater affinity for the $\mu$ receptor. ${ }^{30}$ At the concentrations used in the present study, however, both these receptors would be affected and hence the lack of effect of naloxone alone on fluid and nutrient absorption (Fig. 3) suggests that endogenous opiates do not influence these transport processes in rat small intestine in vitro. This contrasts with the in vivo observations of Fogel and Kaplan ${ }^{31}$ who found that intraluminal naloxone decreased basal ion and water absorption in rat jejunum and ileum. It therefore appears that any endogenous opiates released in vivo are no longer present in in vitro preparations. Because naloxone did not prevent the inhibitory actions of loperamide on nutrient transport (Fig. 3), it seems unlikely that the antiabsorptive effects of loperamide involve an opiate receptor. Other workers ${ }^{32}$ have speculated that the antisecretory actions of loperamide might also involve a non-opiate-receptormediated process.

The ability of loperamide to reduce excessive intestinal secretion is well known, but its inhibitory influence on active nutrient absorption has not been described before. The data presented in this paper are consistent with the view that loperamide acts at the $\mathrm{Na}^{+}$sites of the nutrient carriers, preventing the utilisation of the energy available from the $\mathrm{Na}^{+}$ gradient. This would account for the decreased absorption of nutrients together with the associated reduction in fluid and $\mathrm{Na}^{+}$transport.

We gratefully acknowledge financial support from Janssen Pharmaceutical Ltd.

\section{References}

1 Niemegeers CJE, Lenaerts FM, Janssen PAJ. Loperamide (R18553), a novel type of antidiarrhoeal agent. Part 2. In vivo parenteral pharmacology and acute toxicity in mice. Comparison with morphine, codeine and diphenoxylate. Arzneim Forsch 1974; 24: 1636-41.

2 Schiller LR, Santa Ana CA, Morowski SG, Fordtran JS. Mechanism of the antidiarrhoeal effect of loperamide. Gastroenterology 1984; 86: 1475-80.

3 Beubler E, Lembeck F. Inhibition of stimulated fluid secretion in the rat small and large intestine by opiate agonists. Naunyn-Schmiedebergs Arch Pharmakol 1979; 306: 113-8.

4 Farack UM, Kautz U, Loeschke K. Loperamide reduces the intestinal secretion but not the mucosal cAMP accumulation induced by choleratoxin. Naunyn Schmiedebergs Arch Pharmakol 1981; 317: 178-9.

5 Hardcastle J, Hardcastle PT, Read NW, Redfern JS. The action of loperamide in inhibiting prostaglandininduced intestinal secretion in the rat. Br J Pharmacol 1981; 74: 563-9.

6 Sandhu BK, Tripp JH, Candy DCA, Harries JT. Loperamide: studies on its mechanism of action. Gut 1981; 22: 658-62.

7 Wilson TH, Wiseman G. Use of sacs of everted small 
intestine for the study of the transference of substances from the mucosal to the serosal surface. J Physiol 1954; 123: $116-25$.

8 Krebs HA, Henseleit $K$. Untersuchungen über die Harnstoff bildung im Tierkörper. Hoppe-Seyler's Z Physiol Chem 1932; 210: 33-66.

9 Bray GA. A simple efficient liquid scintillator for counting aqueous solutions in a liquid scintillation counter. Anal Biochem 1960; 1: 279-85.

10 Field M, Fromm D, McColl I. Ion transport in rabbit ileal mucosa. I. $\mathrm{Na}$ and $\mathrm{Cl}$ fluxes and short-circuit current. Am J Physiol 1971; 220: 1388-96.

11 Jorgensen PL. Techniques for the study of steroid effects on membranous $\left(\mathrm{Na}^{+}+\mathrm{K}^{+}\right)$-ATPase. Methods Enzymol 1975; 36: 434-9.

12 Lowry OH, Rosebrough NJ, Farr AL, Randall RJ. Protein measurement with the folin phenol reagent. $J$ Biol Chem 1951; 193: 265-75.

13 Allen RJL. The estimation of phosphorus. Biochem $J$ 1940; 34: 858-65.

14 Fiske CJ, Subbarow Y. The colorimetric determination of phosphorus. J Biol Chem 1925; 66: 375-400.

15 Schultz SG, Zalusky R. Ion transport in isolated rabbit ileum. II. The interaction between active sodium and active sugar transport. J Gen Physiol 1964; 47: 1043-59.

16 Schultz SG, Zalusky R. Interactions between active sodium transport and active amino-acid transport in isolated rabbit ileum. Nature 1965; 205: 292-4.

17 Barry RJC, Eggenton J, Smyth DH. Sodium pumps in the rat small intestine in relation to hexose transfer and metabolism. J Physiol 1969; 204: 299-310.

18 Levin RJ. Fundamental concepts of structure and function of the intestinal epithelium. In: Duthie HL, Wormsley KG, eds. Scientific basis of gastroenterology. Edinburgh: Churchill Livingstone, 1979: 308-37.

19 Hughes S, Turnberg LA. Loperamide: in vitro studies in rabbit ileum and in vivo studies in man. In: Turnberg LA, Intestinal Secretion. Proceedings of the Third BSG.SK \& F International Workshop. Welwyn Garden City: Smith Kline \& French Laboratories, 1983: $98-100$.
20 Verhaeren EHC, Dreessen MJ, Lemli JA. Influence of 1,8-dihydroxyanthraquinone and loperamide on the paracellular permeability across colonic mucosa. $J$ Pharm Pharmacol 1981; 33: 526-8.

21 Schultz SG, Curran PF. Coupled transport of sodium and organic solutes. Physiol Rev 1970; 50: 637-718.

22 Hughes S, Higgs NB, Turnberg LA. Antidiarrhoeal activity of loperamide: studies of its influence on ion transport across rabbit ileal mucosa in vitro. Gut 1982 ; 23: 974-9.

23 Binder $\mathrm{HJ}$. Mechanisms underlying the absorption of water and ions. Int Rev Physiol 1977; 12: 285-304.

24 Frizzell RA, Schultz SG. Models of electrolyte absorption and secretion by gastrointestinal epithelia. Int Rev Physiol 1979; 19: 205-25.

25 Im WB, Misch DW, Powell DW, Faust RG. Phenolphthalein and harmaline induced disturbances in the transport functions of isolated brush-border and basolateral membrane vesicles from rat jejunum and kidney cortex. Biochem Pharmacol 1980; 29: 2307-17.

26 Hughes S, Higgs NB, Turnberg LA. Loperamide has antisecretory activity in vivo in human jejunum. [Abstract]. Gut 1983; 24: A495.

27 Coupar IM. Inhibition by morphine of prostaglandinstimulated fluid secretion in rat jejunum. $\mathrm{Br} J$ Pharmacol 1978; 63: 57-63.

28 Lord JAH, Waterford AJ, Hughes J, Kosterlitz HW. Endogenous opioid peptides: multiple agonists and receptors. Nature 1977; 207: 495-9.

29 Kachur JF, Miller RJ, Field M. Control of guinea pig intestinal electrolyte secretion by a $\delta$-opiate receptor. Proc Natl Acad Sci 1980; 77: 2753-6.

30 Chang KJ, Cuatrecasas P. Multiple opiate receptors. J Biol Chem 1979; 254: 2610-8.

31 Fogel R, Kaplan RB. Role of enkephalins in regulation of basal intestinal water and ion absorption in the rat. Am J Physiol 1984; 246: G386-G392.

32 Binder HJ, Laurenson J, Dobbins JW. Mechanism of loperamide's anti-diarrhoeal action. Gastroenterology 1981; 80: 1111. 